\title{
Cost Optimization in Batch Industrial Salami Ripening through Mathematical Modeling
}

\author{
Giovanni Cascone, Michele Miccio, Carlo Diaferia, Massimiliano Dodaro, Michela Fraganza, Franco Longo, Lucia Seta
}

\begin{abstract}
Within a recent research project (PON Safemeat) devoted to "innovative" fresh and fermented meat-based products, the project partners' chambers were used for salami ripening and a number of experimental tests were carried out under strictly controlled conditions. In addition to both process and product data obtained during ripening, the PON Safemeat has also allowed focusing on production cost data. Therefore, a mathematical model was developed to express costs associated to the industrial batch ripening of salami and an objective function was devised with the goal of optimization.
\end{abstract}

The model considers the cost of raw materials, the operating costs (linearly increasing with time during maturing) and, finally, a cost for the "loss of quality" of an off-specification product, expressed as a "non-revenue" and referred to as "QL factor". The objective function is a nonlinear function of the nondimensional time $t *$

Two test cases have been constructed by considering Italian traditional sausage products, i.e., the spicy "Soppressata A" produced by Dodaro SpA and the "Salame of Felino", and the corresponding results have been analyzed and compared. The outcome of this work is interesting at present and promising in the future for further development and validation activities.

Keywords - Ripening chamber, Salami, Mathematical Model, Optimization

\section{Introduction}

Salami are dried and fermented meat-based food that are traditionally consumed in different areas of the world. They are commonly investigated in food science and technology (e.g., Katz and Stinsky, 1987) as well as in engineering design, modeling and simulation (Grassi and Montanari, 2005; Cascone et al., 2015; Cascone et al., 2017).

The largely prevailing process in the salami production from fresh sausages is dehydration. The final product weight loss is high enough, generally about $1 / 3$ of the initial weight, $20 \%$ of which is in the first processing week (Diaferia et al., 2011). The whole sausage ripening process consists of a sequence of phases, as the following (Zambonelli et al., 1992):

- $\mathbf{1}^{\text {st }}$ phase: stabilization of the introduced product. Chamber temperature: $5-7^{\circ} \mathrm{C}$. It is aimed at obtaining a uniform product temperature, before start-up of the drying process. This phase is used only if the product loading time in the chamber is high and so it is necessary to avoid initial temperature differences.

- $\quad 2^{\text {nd }}$ phase: low temperature drying at $7-8{ }^{\circ} \mathrm{C}$. This phase allows a weight loss of $2 \%$ in $12-20$ hours and guarantees drying of the casing, which are very moistened because just washed. Only a few producers are equipped and actually adopt this phase.

- $\quad 3^{\text {rd }}$ phase: heating. In this phase the product attains a core temperature of about $18-20^{\circ} \mathrm{C}$; the duration of the heating stage is a function of the chamber temperature, the sausage size and shape and the meat quality. A small weight loss is allowed by controlling the chamber relative humidity $(\mathrm{RH})$. In this phase, temperature and a high humidity facilitate the sausage typical fermentation, which will give the distinctive taste and characteristic flavor.

- $\quad 4^{\text {th }}$ phase: actual drying. A strong dehydration and a drop in the chamber temperature characterize this phase, which results in the end of the above said fermentation. Beginning temperature: $18-22^{\circ} \mathrm{C}$, RH: $50-75 \%$.

- $\quad 5^{\text {th }}$ phase: ripening. This phase is a drying phase too, but at a milder rate. The chamber temperature decreases from an initial value of $17^{\circ} \mathrm{C}$ down to 12 $13^{\circ} \mathrm{C}$; $\mathrm{RH}$ is about $55-85 \%$.

Fully automated operation of the ripening chamber ensures uniform circulation of curing air within the volume occupied by sausages inside the chamber.

Within a recent research project (PON Safemeat) aimed at the development of "innovative" methods for the production of low-fat, fresh and cured meat products, with the addition of functional starters, a well-structured experimental program was carried out. For salami ripening, the project partners' chambers were used under strictly controlled conditions, including the pilot-scale, air ascending-flow cell of the Experimental Station for Food Preserving Industry (SSICA) at Parma (IT). In addition to process and product data obtained during ripening, the PON Safemeat project allowed focusing on production cost data, too. This triggered the idea of developing a mathematical model of costs associated to the industrial batch ripening of salami with the goal of optimization.

Optimization with mathematical models of industrial salami ripening is not very much treated in literature. Tradition and rules of thumb hold, whereas many actions and decisions are taken by process technologist on the basis of his personal experience and historical data log. Imre and Kornyey (1990) elaborated a dynamic drying algorithm for salami and set up an automatic ripening control strategy. Bertolini et al. (2006), based on previous modeling works for the fluid-dynamic and thermal simulation of the above SSICA pilot cell (Grassi and Montanari, 2005), simulated and validated the batch ripening process for different salami. In addition, from the analysis of 
the low-period oscillation of the air flow into the cell, they found a particular configuration that optimizes the batch from the viewpoint of uniformity in the weight loss of individual sausages.

This work shows the development, the implementation and the first results of an optimization model that can determine both the optimal time and the minimum cost in the industrial production of a salami batch, with an approach that is simple, but able of dealing with quality and safety required for commercial dry sausages.

\section{Materials and Methods}

Two types of sausage products have been considered: the spicy "Soppressata A" produced by Dodaro SpA under the PON SafeMeat project in 2013 (Autori Vari, 2013) and the "Salame of Felino" (Dellapina et al., 1994). Their typical industrial production data are shown in Table I.

TABLE I. INDUSTRIAL Production DATA OF THE TESTEd SALAMI

\begin{tabular}{|l|c|c|}
\hline \multicolumn{1}{|c|}{ Datum } & $\begin{array}{c}\text { Soppressata } \\
\text { piccante } A\end{array}$ & $\begin{array}{l}\text { Salame di } \\
\text { Felino }\end{array}$ \\
\hline $\begin{array}{l}\text { Ripening time adopted by the } \\
\text { manufacturer } \mathrm{t}_{\mathrm{p}}[\mathrm{d}]\end{array}$ & 34 & 45 \\
\hline $\begin{array}{l}\text { Weight loss declared by the manufacturer } \\
\text { at the end of ripening } \Delta_{\mathrm{mp}}[\%]\end{array}$ & 40.0 & 32.5 \\
\hline $\begin{array}{l}\text { Cost of the raw materials used on the } \\
\text { fresh } \mathrm{C}_{\mathrm{mp}}[€ / \mathrm{kg}]\end{array}$ & 3.25 & 3.50 \\
\hline $\begin{array}{l}\text { Final cost of the ripened product } \mathrm{C}_{\mathrm{p}} \\
{[€ / \mathrm{kg}]}\end{array}$ & 5.5 & 9.0 \\
\hline
\end{tabular}

Two ripening chambers of the same type, i.e., with an air ascending-flow pattern, were used in the experimental program: the pilot-scale cell of SSICA at Parma (IT) and the industrial-scale chamber of Dodaro SpA at Spezzano Albanese (IT).

The weight loss during ripening was predicted by a mathematical model developed by the authors and implemented with the Comsol Multiphysics@ software (Cascone et al., 2015). The implementation of cost functions and the search for the minimum cost were made with the MS Excel® software. Mathematical functions for fitting the individual cost components have been identified with the Curvefit@ software.

\section{Mathematical Model}

\section{A. Simulation of ripening}

The aforementioned Comsol Multiphisics ${ }^{\circledR}$ code has been used to determine the minimum time $t_{\min }$ for ripening a batch of sausages while maintaining the same "commercial" weight loss declared by the manufacturer. In other words, "pushing" conditions for curing air have been adopted to get an "accelerated" ripening, by setting the code (Cascone et al.,
2015) to run a simulation for each product under forced convection conditions only, with a choice of air velocity, humidity and temperature corresponding to the maximum permissible values in a ripening chamber. The data set for each product in input to the calculation code and the resulting values of the minimum ripening time are shown in Table II.

TABLE II. InPUt DATA TO THE COMSOL MULTIPHISICS® CODE AND MINIMUM PREDICTED TIME

\begin{tabular}{|c|c|c|}
\hline Parameter & $\begin{array}{l}\text { Soppressata } \\
\text { piccante } A\end{array}$ & $\begin{array}{l}\text { Salame di } \\
\text { Felino }\end{array}$ \\
\hline Curing air temperature $[\mathrm{K}]$ & 296 & 296 \\
\hline Initial salami temperature $[\mathrm{K}]$ & 283.16 & 275.0 \\
\hline Initial $\mathrm{H}_{2} \mathrm{O}$ mass fraction of salami & 0.6281 & 0.6350 \\
\hline Initial salami mass $[\mathrm{g}]$ & 604 & 1200 \\
\hline Salami length [mm] & 150 & 525 \\
\hline Salami diameter $[\mathrm{mm}]$ & 80.0 & 57.5 \\
\hline Initial relative humidity of curing air & 0.50 & 0.50 \\
\hline Air velocity $[\mathrm{m} / \mathrm{s}]$ & 1 & 1 \\
\hline $\begin{array}{l}\text { Maximum calculation time set for the } \\
\text { simulation [d] }\end{array}$ & 34 & 37 \\
\hline \multicolumn{3}{|c|}{ Minimum ripening time resulting from the simulation } \\
\hline $\mathrm{t}_{\min }[\mathrm{d}]$ & 20 & 7 \\
\hline
\end{tabular}

\section{B. Cost and Objective Function}

The unit cost of producing a batch of industrial salami is determined by the following components, with the following assumptions:

- cost of raw materials known and independent of ripening;

- operating costs (resulting from the use of plants, labor, energy, etc.) linearly increasing with time during maturing;

- cost associated with the "loss of quality" of the product, expressed as a "non-revenue" and referred to as "QL factor".

The following additional assumptions were made:

_ _ _factor $Q L "$ = "zero" at the "optimal" ripening time;

- $\quad$ "factor $Q L ">$ > "zero" at times different from the "optimal" and precisely:

decreasing with time during the drying phase and the first part of the ripening,

increasing with time if the ripening is prolonged beyond an optimal time.

This takes into account the adverse effect that a too short or too long processing time has on food quality and safety. Therefore, the objective function representing the "unit cost of industrial production of salami" is the following:

$$
\begin{aligned}
\frac{\mathrm{C}\left(\mathrm{t}^{*}\right)}{\mathrm{W}_{\text {batch }}}= & \mathrm{C}_{\mathrm{mp}}+\mathrm{d}_{1} \mathrm{t}^{*}+\left(\mathrm{a}_{1}+\mathrm{b}_{1} \mathrm{t}^{*}+\mathrm{c}_{1} \mathrm{t}^{* 2}\right)_{\mathrm{t}^{*} \leq \mathrm{t}_{\mathrm{p}}^{*}}+ \\
& +\left(\mathrm{a}_{2}+\mathrm{b}_{2} \mathrm{t}^{*}+\mathrm{c}_{2} \mathrm{t}^{* 2}\right)_{\mathrm{t}^{*}>\mathrm{t}_{\mathrm{p}}^{*}}
\end{aligned}
$$

where:

$\mathrm{C}\left(\mathrm{t}^{*}\right)[€] \quad$ is the total production cost for a salami batch at time $\mathrm{t}^{*}$; 
Proc. of the Sixth International Conference on Advances in Civil, Structural and Environmental Engineering - ACSEE 2017. Copyright (c) Institute of Research Engineers and Doctors. All rights reserved.

ISBN: 978-1-63248-139-9 doi: 10.15224/ 978-1-63248-139-9-30

\begin{tabular}{|c|c|}
\hline $\mathrm{W}_{\text {batch }}[\mathrm{kg}]$ & $\begin{array}{l}\text { is the industrial salami batch } \\
\text { weight; }\end{array}$ \\
\hline $\begin{array}{l}\mathrm{C}_{\mathrm{mp}}[€ / \mathrm{kg}] \\
\mathrm{d}_{1}[€ /(\mathrm{kg} \mathrm{d})]\end{array}$ & $\begin{array}{l}\text { is the unit cost of raw materials; } \\
\text { is the unit labor cost coefficient for } \\
\text { the processing time; }\end{array}$ \\
\hline$a_{1}, b_{1}, c_{1}$ & $\begin{array}{l}\text { are coefficients to express non- } \\
\text { revenue for "premature" product; }\end{array}$ \\
\hline$a_{2}, b_{2}, c_{2}$ & $\begin{array}{l}\text { are coefficients to express non- } \\
\text { revenue for "overprocessed" } \\
\text { product; }\end{array}$ \\
\hline $\mathrm{t}[\mathrm{d}]$ & $\begin{array}{l}\text { is the current time in industrial } \\
\text { ripening of a salami batch; }\end{array}$ \\
\hline $\mathrm{t}_{\min }[\mathrm{d}]$ & is the minimum time for an \\
\hline & $\begin{array}{l}\text { "accelerated" ripening, under } \\
\text { "pushed" conditions, of a salami } \\
\text { batch; }\end{array}$ \\
\hline $\mathrm{t}_{\mathrm{p}}[\mathrm{d}]$ & is the end-of-ripening \\
\hline & $\begin{array}{l}\text { reference adopted by the } \\
\text { manufacturer on the basis of his } \\
\text { experience; }\end{array}$ \\
\hline $\mathrm{t}^{*}=\mathrm{t} / \mathrm{t}_{\min }$ & is the non-dimensional time. \\
\hline
\end{tabular}

The predicted minimum time $t_{\text {min }}$ is used to make the time non-dimensional during maturing. This gives the advantage of making cost curves less linked to specific products and ripening, and of reducing the large cost variability over the time among different products and ripening conditions, thanks to a "reference simulation" for ripening that is always conducted in the same conditions for curing air.

The operating cost $\mathrm{d}_{1} \mathrm{t}[€ / \mathrm{kg}]$, proportional to the current working time in the industrial curing chamber, is represented by a positive slope line that has an intercept equal to $\mathrm{C}_{\mathrm{mp}}$ at time $\mathrm{t}=0$. Based on the hypotheses made, the "QL factor" (non-revenue) is expressed by a curve having a minimum value $\mathrm{QL}=0$ at the end-of-ripening reference time $t_{\mathrm{p}}$. In addition, it was hypothesized that the variation of the "QL factor" remains sufficiently flat in the days preceding and following the end of ripening time $t_{p}$ adopted by the producer and is less marked in a product that has undergone an excessive maturation (i.e., $t>t_{p}$ ), compared to the one just ripened for a lower time (i.e., $\mathrm{t}<\mathrm{t}_{\mathrm{p}}$ ). This reflects the commercial experience under which the product has a wide acceptability range around $t_{p}$ and the variation in the loss of value (lack of revenue) is larger in a "premature" product than in an "overprocessed" one. $t^{*}$.

It is worth noting that $\mathrm{C}\left(\mathrm{t}^{*}\right)$ is a nonlinear function of time

\section{Results and Discussions}

For the unit cost of raw materials, independent of the current working time, the data provided by the manufacturer have been used (see Table I). The estimate of the other coefficients was possible thanks to a mathematical curve fitting procedure, triggered by producer cost data (see Table I). The procedure is described below:
1. Calculate $t_{\min }$ based on the mathematical model with the COMSOL computing code;

2. Posed that the curve of the failed revenues had a reasonably decreasing trend for $t<t_{p}$ from $Q L=5 C_{m p}$ at $t=0$ to the minimum $Q L=0$ at $t_{p}$, the coefficients $a_{1}, b_{1}, c_{1}$ were evaluated;

3. Posed that the curve of the failed revenue had a quadratic trend for $t>t_{p}$ with a minimum $Q L=0$ at time $t_{p}$ and $a$ value $Q L=0.3 C_{p}$ at $t=1.5 t_{p}$ (50\% longer than the end-ofripening time in industrial production), the coefficients $a_{2}$, $b_{2}, c_{2}$ were evaluated;

4. Posed that the straight line of operating costs (between all the lines of the beam passing through $C_{m p}$ ) had a slope $d_{1}$ such that it determined a value of the total cost curve equal to $C_{p}$ at time $t_{p}$ (end-of-ripening cost and time in industrial production), this allowed $d_{1}$ to be evaluated;

5. Once the cost components have been defined, the objective function is available as a total curve and its minimum identifies the optimum time $t_{o}{ }^{*}$.

The time was made non-dimensional by taking $t_{\min }=20 \mathrm{~d}$ and $\mathrm{t}_{\min }=7 \mathrm{~d}$, as a result of simulations, for the the spicy "Soppressata A" and "Salame of Felino", respectively. As a consequence, the manufacturer's reference non-dimensional time for optimal maturation is $t_{p} *=1.7$ (corresponding to $t_{p}=$ $34 \mathrm{~d}$ ) and $\mathrm{t}_{\mathrm{p}} *=6.43$ (corresponding to $\mathrm{t}_{\mathrm{p}}=45 \mathrm{~d}$ ), for the spicy "Soppressata A" and "Salame of Felino", respectively.

Using the available data set, the coefficients involved in the general $\mathrm{C}\left(\mathrm{t}^{*}\right)$ objective function were determined and are reported for each product in Table III.

TABLE III. COEFFICIENTS OF THE CURVE OF TOTAL COSTS FOR THE INVESTIGATED SALAMI

\begin{tabular}{|r|r|r|}
\hline & $\begin{array}{c}\text { Soppressata } \\
\text { piccante A }\end{array}$ & $\begin{array}{c}\text { Salame di } \\
\text { Felino }\end{array}$ \\
\hline $\mathrm{d}_{1}$ & 1.319 & 0.856 \\
\hline $\mathrm{a}_{1}$ & 16.25 & 17.5 \\
\hline $\mathrm{b}_{1}$ & -19.657 & -5.432 \\
\hline $\mathrm{c}_{1}$ & 5.943 & 0.421 \\
\hline $\mathrm{a}_{2}$ & 6.642 & 9.033 \\
\hline $\mathrm{b}_{2}$ & -7.809 & -2.906 \\
\hline $\mathrm{c}_{2}$ & 2.295 & 0.233 \\
\hline
\end{tabular}

Fig. 1 shows the calculated cost curves.

From Fig. 1 we see that the total cost has a minimum at $\mathrm{t}_{\mathrm{o}}{ }^{*}=1.55$ corresponding to $\mathrm{t}_{\mathrm{o}}=31 \mathrm{~d}$, which advantageously anticipates the industrial ripening time $t_{p}=34 \mathrm{~d}$ for the Spicy "Soppressata A". Moreover, a minimum is detected for total cost at $t_{0} *=5.43$ corresponding to $t_{o}=38 d$, also in advance with respect to the end-of-ripening time $t_{p}=45 \mathrm{~d}$, for "Salame of Felino" (Figure 1). At $\mathrm{t}_{\mathrm{p}}{ }^{*}$ the cost value is the same as that provided by the manufacturer, i.e., $5.5 € / \mathrm{kg}$ for the Spicy "Soppressata A" and $9.0 € / \mathrm{kg}$ for the "Salame of Felino", whereas the costs will be $5.35 € / \mathrm{kg}$ for the first and $8.58 € / \mathrm{kg}$ 
Proc. of the Sixth International Conference on Advances in Civil, Structural and Environmental Engineering - ACSEE 2017. Copyright (c) Institute of Research Engineers and Doctors. All rights reserved.
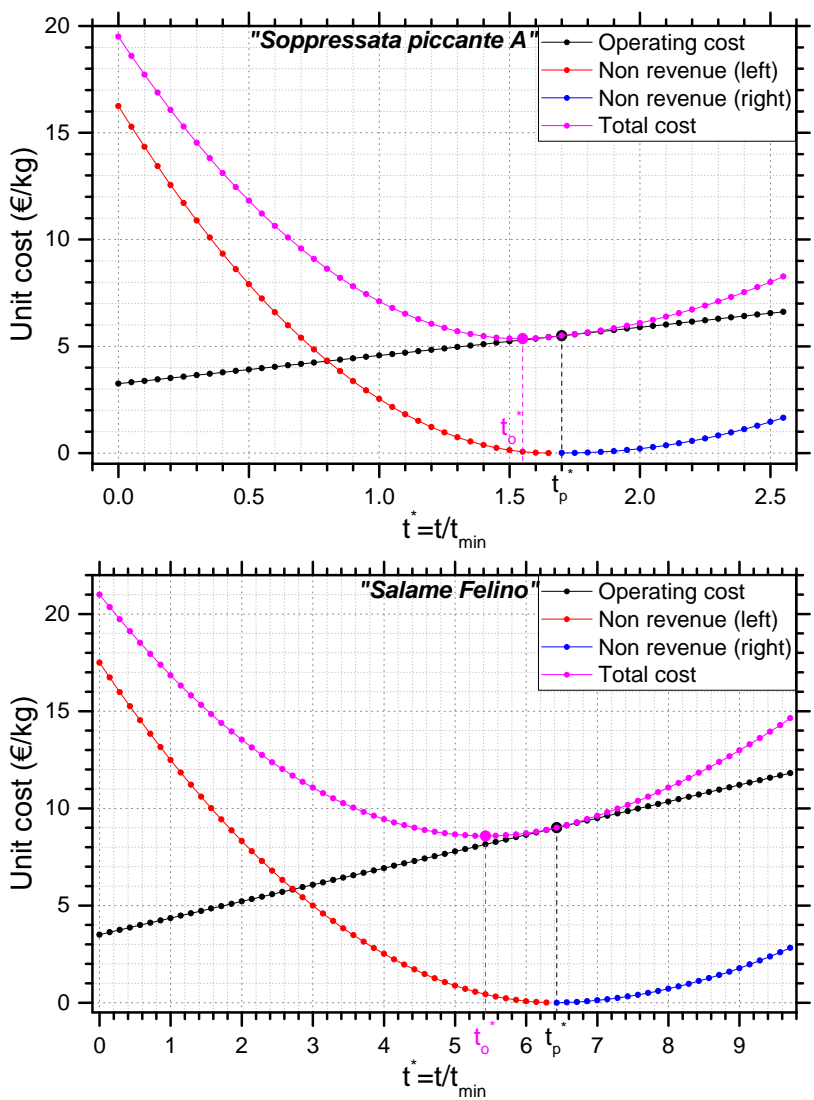

Figure 1. Individual and total cost for a salami batch as a function of processing time, with determination of the optimum

for the second one, thus allowing a producer to make a saving, thanks to the possibility of anticipating the end of maturing 3 days for the first one and 7 days for the other one.

\section{v. Conclusions and Future Developments}

The proposed optimization model, in this first application, allows identifying optimum maturing times that appear lower than those known by industrial practice for the types of salami taken into account. This highlights the possibility of lowering the maturing costs (by shortening the duration) without affecting the quality of the product. Further validation work for other salami is needed in relation to their cost and ripening data. It is also desirable to identify more strictly the loss of product quality ("non-revenue") over time through the economic impact that an incomplete or excessive ripening may have on the commercialized product.

The optimization model promises to improve its credibility and usage when appropriately interfaced with a predictive mathematical model of the sausage ripening under more realistic conditions, for instance by taking "phase-after-phase" maturing into account, instead of uniform "pushing" conditions.

\section{Acknowledgments}

The authors' gratitude goes to the actors and financial support of the research project PON01_01409 "Safemeat", call for Research and Competitiveness 2007-2013, decree No. 671 of the Italian Ministry of Education and Research.

\section{References}

[1] Autori Vari, "Rapporto Tecnico su Stato Avanzamento n.4" 15.04-14.10.2013 PON SAFEMEAT, 2013

[2] Bertolini M., Ferretti G., Grassi A., Montanari R., "Ripening process design optimization for an ascending flow ripening chamber". Journal of Food Engineering, 77, 529-538, 2006

[3] Cascone G., Miccio M., Dodaro M., Longo F., Seta L., "Modeling and simulation of fermented sausages ripening with a heterogeneous porous media approach", Chemical Engineering Transactions, DOI: 10.3303/CET1757339, 57, 2029-2034, 2017

[4] Cascone G., Setegn H.G., Miccio M. and Diaferia C., "A tool for modeling and simulation of irregular shape and shrinking salamis during drying", Chemical Engineering Transactions, Editors: Sauro Pierucci and Jiř́ J. Klemeš, 43, 103-108, 2015

[5] Dellapina G., Blanco D., Pancini E., Barbuti S., Campanini M., "Andamento microbiologico nella produzione di salami italiani, tipo Felino, Milano e Ungherese". Industria Conserve, 69, 85-90, 1994

[6] Diaferia C., Miccio M., Baldini P., Castellani L., De Rosa M.L., Fragranza M., Lanni A., "Codice di simulazione e potenzialità predittive per la stagionatura di salami tradizionali", Industria Conserve, 86, 161-173, 2011

[7] Grassi A., Montanari R., "Simulation of the thermodynamic patterns in an ascending flow ripening chamber". Journal of Food Engineering, $68,113-123,2005$

[8] Imre L. and T. Kornyey, "Computer simulation of salami drying". International Journal for numerical methods in Engineering, 30, 767 777, 1990

[9] Katz P. and Stinsky H., "Determining optimum drying conditions for dry sausage products in ripening rooms", Fleischwirtschaft, 67(10), 1188,1987

[10] Zambonelli Carlo, Luigi Grazia, Fausto Papa, Patrizia Romano, giovanna Suzzi, Microbiologia dei salumi, Edagricole - New Business Media, 1992, pp.170-173 